\title{
Pengaruh Kinerja Distribusi Selling-In Terhadap Kinerja Pemasaran PR. Gagak Hitam
}

\section{The Influence of Distribution Selling-In on Marketing Performance PR. Gagak Hitam}

\author{
Fredy Eka Ardhi Pratama ${ }^{\# 1}$, Hariadi Subagja ${ }^{2}$, Ridwan Iskandar ${ }^{3}$, Huda Ahmad Hudori $^{4}$, Paramita \\ Andini $^{5}$ \\ ${ }^{\#}$ Program Studi Manajemen Agroindustri, Jurusan Manajemen Agribisnis, Politeknik Negeri \\ Jember
}

Jalan Mastrip 164 Jember Jawa Timur, Indonesia

${ }^{1}$ fredyekaa@gmail.com

\begin{abstract}
The successful performance of a company selling-in one of them by building a good relationship between the company with its customers so as to be able to face global competition. This research attempts to answer the phenomenon of business on PR. Gagak Hitam Maesan Bondowoso which shows the tendency of marketing performance, especially the realization of sales below the sales target and relatively fluctuate. Developed a study formed from literature review in order to answer the business phenomenon. This research model is also based on previous research. A model has been developed and seven hypotheses have been formulated to address this research problem. The sampling technique used purposive sampling. Respondents from this study amounted to 114 respondents, where respondents were 114 samples of the owners or responsible person outlets who sell products from PR. Gagak Hitam Maesan Bondowoso. The data analysis tool used is Structural Equation Modeling (SEM) in AMOS 22 program. The results of this research data analysis show the model and research results can be received well. This study proves that distributor relationship with outlet has a direct and insignificant effect on selling-in performance. The ability of the sales force has a direct and significant impact on the selling-in performance. Corporate image has a direct and significant impact on sales-in performance. Outlet service strategy has a direct and insignificant effect on selling-in performance. Selling-in performance has a direct and insignificant influence on marketing performance. The distributor's relationship with the outlet has a direct and insignificant influence on marketing performance. Outlet service strategy has a direct and insignificant influence on marketing performance. Managerial implications and research agenda were also discussed in this study. Some limitations of research and future research agenda can be used as a reference for further researchers.
\end{abstract}

Keywords: Distributor Relationship with Outlet, Ability of Marketing Personnel, Corporate Image, Outlet Service Strategy and Selling-in, Marketing Performance.

\section{PENDAHULUAN}

Perkembangan dunia usaha yang begitu cepat merupakan sebuah tantangan yang harus dihadapi oleh perusahaan, dimana tidak hanya strategi untuk dapat mempertahankan diri dari keadaan tertentu melainkan harus mampu memiliki keunggulan bersaing terhadap kompetitor produk sejenis. PR. Gagak Hitam perusahaan yang bergerak di bidang industri rokok selain memberikan atau menyediakan produk yang dibutuhkan konsumen, perusahaan juga harus mau menanggapi keluhan dan saran dari konsumen. Strategi ini dilakukan sebagai bentuk upaya dalam meningkatkan dan mendekatkan perusahaan kepada konsumen [1].

Pemasaran Rokok Kretek Gagak Hitam di Kabupaten Bondowoso dan Kabupaten Situbondo belum optimal karena realisasi pemasaran dibawah target pemasaran dan relatif berfluktuasi. Pada tahun 2012 kemudian tahun 2011 mengalami penurunan 
penjualan dan 2013 menunjukkan penurunan yang sangat signfikan jika dibandingkan dengan tahun sebelumnya. Tahun 2014 mengalami sedikit kenaikan dari tahun 2013, sedangkan tahun 2015 mengalami penurunan penjualan jika di bandingkan dengan sebelumnya. Penurunan dan kenaikan penjualan rokok kretek Gagak Hitam dikarenakan pesaing lokal rokok kretek "Gagak Hitam" merupakan suatu ancaman pesaing bagi rokok kretek "Gagak Hitam" karena harga yang ditawarkan cukup kompetitif.

Segmen pasar produk rokok jenis kretek "Gagak Hitam" merupakan kalangan menengah ke bawah. Rokok kretek bermerek dagang "Gagak Hitam" merupakan rokok yang sebenarnya diminati oleh konsumen, tetapi ada beberapa permasalahan yang membuat rokok tersebut mengalami penurunan penjualan. Permasalahan produk rokok kretek "Gagak Hitam" antara lain rasa rokok, tembakau kurang kering, ukuran rajangan tembakau terlalu besar, bahan isian terlalu padat sehingga berpengaruh kepada hisapannya, keropos di bagian tertentu, terdapat noda (spot), dan tidak tercantum tanggal dan tahun kadaluarsa. Kendala-kendala tersebut merupakan permasalahan dari sisi kualitas produk, sehingga perlu dilakukan perbaikan. Kondisi ini tentu tidak dapat diabaikan oleh pihak manajemen karena dari kondisi tersebut juga berhubungan dengan kinerja distribusi selling-in yang telah dicapai.

Terdapat research gap antara pengukuran sellingin dengan dilatar belakangi perbedaan hasil penelitian Sunaryo [2] selling-in dipengaruhi oleh strategi pelayanan outlet, hubungan dengan outlet, citra perusahaan, citra perusahaan dan aktivitas kompetitor. Faktor yang paling berpengaruh terhadap kinerja selling-in adalah hubungan dengan outlet. Selling-in dipengaruhi oleh beberapa faktor, yaitu strategi pelayanan outlet, hubungan dengan outlet dan citra perusahaan [3]. Faktor yang paling berpengaruh terhadap kinerja selling-in adalah citra perusahaan. Selling-in dipengaruhi oleh kemampuan tenaga pemasar, strategi pelayanan outlet dan hubungan dengan outlet. Faktor yang paling berpengaruh terhadap kinerja selling-in adalah kemampuan tenaga pemasar [4].

Teori gap yang mendukung penelitian ini untuk dijadikan sebuah variabel hubungan distributor dengan outlet diposisikan sebagai kunci pengikat hubungan kerjasama. Hubungan distributor dengan outlet merupakan sesuatu yang penting dalam sebuah mekanisme pencapaian menuju kinerja pemasaran yang superior [5]. Keterkaitan kemampuan tenaga pemasar dalam memperkuat hubungan antara distributor dan outlet, namum hasil penelitian dirasakan masih jauh dari harapan peneliti Adikusumo (2003) ${ }^{[6]}$. Keahlian (kemampuan) tenaga pemasar memiliki berpengaruh secara signifikan dan dominan dalam sebuah hubungan pemasaran. Pengukuran strategi distribusi berbasis selling-in lainnya adalah strategi pelayanan outlet. Kunci kearah sukses jangka panjang terletak pada strategi pelayanan outlet. Strategi pelayanan outlet ditunjukan untuk dapat dengan cepat merespon dan kepekaan perusahaan terhadap lingkungannya [7]. Pengukuran pengaruh strategi pelayanan outlet dengan kinerja pemasaran, namun hasil penelitian menunjukkan hasil yang tidak memuaskan. Berdasarkan kesimpulan tersebut, penelitian ini mengangkat strategi pelayanan outlet sebagai topik yang layak untuk diteliti lebih lanjut [8].

Berdasarkan latar belakang permasalahan (research problem) dan kesenjangan penelitian yang ada (research gap), penelitian ini mencoba melihat permasalahan yang terjadi pada PR. Gagak Hitam yaitu faktor-faktor seperti hubungan distributor terhadap outlet, kemampuan tenaga pemasaran, citra perusahaan dan strategi pelayanan outlet merupakan variabel-variabel yang mempengaruhi kinerja distribusi selling-in serta relevansinya terhadap peningkatan kinerja pemasaran.

Tujuan penelitian ini adalah untuk menganalisis pengaruh hubungan distributor dengan outlet terhadap distribusi selling-in, pengaruh kemampuan tenaga pemasaran terhadap distribusi selling-in, pengaruh citra perusahaan terhadap distribusi sellingin, pengaruh strategi pelayanan outlet terhadap distribusi selling-in dan pengaruh kinerja distribusi selling-in terhadap kinerja pemasaran serta pengaruh hubungan distributor dengan outlet terhadap kinerja pemasaran, pengaruh strategi pelayanan outlet terhadap kinerja pemasaran.

\section{METODOLOGI}

Penelitian ini dilakukan pada bulan Oktober sampai Desember 2016 dengan lokasi penelitian PR. (Perusahan Rokok) Gagak Hitam Kecamatan Maesan Kabupaten Bondowoso. Lokasi penelitian tersebut dipilih dengan sengaja (purposive) yang merupakan perusahaan agribisnis yang bergerak di bidang produksi rokok sigaret kretek tangan (SKT) dan sigaret kretek mesin (SKM) yang berpusat di Maesan Bondowoso.

Penentuan didasarkan pada Teknik pengambilan sampel (tehnik sampling) yang dipakai adalah Purposive Sampling yaitu teknik penentuan sampel dengan pertimbangan tertentu, yaitu :

1. Responden adalah para pemilik atau pengelola outlet.

2. Hubungan mitra rekanan antara distributor dengan outlet minimal 6 bulan menjadi rekanan PR. Gagak Hitam.

3. Pendistribusian outlet rata-rata per / bulan diatas Rp 2.000.000

Pengambilan sampel juga didasarkan pada masing-masing area, yaitu Kabupaten Bondowoso 69 sampel dan Kabupaten Situbondo 45 sampel, total $114 \mathrm{sampel} / \mathrm{responden}$. 
Fredy Eka Ardhi Pratama, Hariadi Subagja, Ridwan Iskandar, Huda Ahmad Hudori, Paramita Andini. Pengaruh Kinerja Distribusi Selling-In Terhadap Kinerja Pemasaran PR. Gagak Hitam

Analisis yang digunakan untuk menguji hipotesis dalam penelitian ini adalah model persamaan struktural (Structural Equation Modeling atau SEM) dengan menggunakan paket program AMOS (Analysis of Moment Structure) versi 22. Data yang terkumpul dianalisis dengan analisis SEM yang merupakan penggabungan dari analisis jalur (path analysis) dan model pengukuran (measurement model) yaitu analisis faktor (Confirmatory Factor Analysis). Secara umum, alat analisis utama dalam penelitian ini yaitu alat uji asumsi SEM dan alat uji kecocokan model.

Uji asumsi SEM, Ukuran sampel disarankan lebih dari 100 atau minimal 5 kali jumlah observasi. Uji normalitas data dipergunakan tingkat signifikasi 5\% (0.05), maka nilai CR yang berada diantara $-1,96$ sampai dengan $1,96(-1,96 \leq \mathrm{CR} \leq 1,96)$ dikatakan data distribusi normal, baik secara univariate maupun secara multivariate [9]. Uji Outlier adalah kondisi obervasi dari suatu data yang memiliki karakteristik unik yang terlihat sangat berbeda jauh dari observasiobservasi yang lainnya, dan muncul dalam bentuk nilai ekstrim, baik untuk sebuah variabel tunggal maupun untuk variabel-variabel kombinasi. Uji multikolinieritas dilakukan untuk mengetahui apakah antara variabel pada model yang sempurna. Nilai determinan yang sangat kecil atau sama dengan 0 (nol) diindikasikan adanya masalah multikolinearitas atau singularitas, sehingga tidak dapat digunakan dalam penelitian.

Uji kecocokan model terdiri dari Goodnessof Fit Test dan uji pengaruh (RegressionWeight). Ada dua model yang akan diuji secara simultan, yaitu: (1) model pengukuran (measurement model), dan (2) model struktural (structural model).

Langkah-langkah atau prosedur dalam mengaplikasi model persamaan struktural adalah antara lain Langkah 1: membangun model berbasis teori, yang menjelaskan hubungan sebab-akibat dengan justifikasi teoritis dari manajemen sumber daya manusia.

Langkah 2: pengembangan diagram jalur. Model yang dibangun pada langkah-1, digambarkan dalam bentuk diagram jalur. Konstruksi yang dibangun pada diagram jalur dibedakan menjadi dua konstruksi, yaitu: konstruk eksogen dan konstruk endogen

Langkah 3: mengkonversi diagram jalur menjadi persamaan model struktural, persamaan struktural diajukan dalam model konseptual penelitian pada Gambar 1. berikut ini:

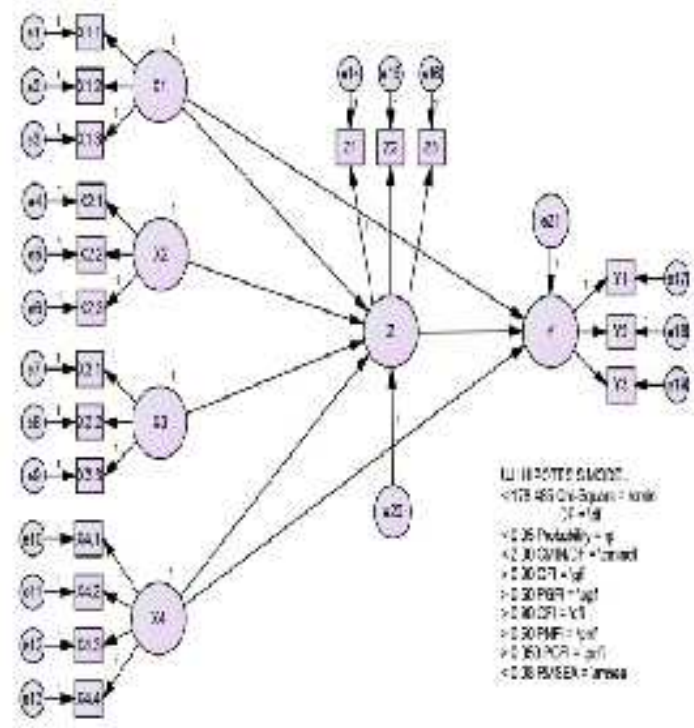

GAMBAR 2.FORMULASI MODEL SEM

Keterangan gambar:

Variabel Bebas (Laten Eksogen)

Indikator Hubungan Dengan Outlet $\left(\mathrm{X}_{1}\right)$

$\mathrm{X} 1.1=$ Intensitas Kontak atauKomunikasi

$\mathrm{X} 1.2$ = Lama Hubungan

X1.3 = Tingkat Kepercayaan

Indikator Kemampuan Tenaga Pemasaran $\left(\mathrm{X}_{2}\right)$

$\mathrm{X} 2.1$ = Tingkat Ketrampilan Berbicara

$\mathrm{X} 2.2$ = Ketepatan

$\mathrm{X} 2.3$ = Profesionalitas

Indikator Citra Perusahaan $\left(\mathrm{X}_{3}\right)$

X3.1 = Kesadaran Merk atau Brand Awareness

X3.2 = Kemampuan Manajemen

X3.3 = Komitmen Perusahaan

Indikator Strategi Pelayanan Outlet $\left(\mathrm{X}_{4}\right)$

X4.1 = Kunjungan $($ call $)$

$\mathrm{X} 4.2$ = Periode Pembayaran

X4.3 = Kebijakan Return (Term of Payment)

X4.4 = Contract (Buy and Sales)

Variabel Antara (Intervening) Indikator Selling-In (Z)

Z1 = Kelengkapan Barang atau Produk

Z2 = Tingkat Pelayanan

Z3 = Tingkat Persediaan (Stock Level)

Variabel Terikat (Laten Endogen) Indikator

Kinerja Pemasaran (Y)

Y1 = Volume Penjualan atau Sales Volume

Y2 = Pertumbuhan Penjualan atau Sales Growth

Y3 = Pertumbuhan Pelanggan

Langkah 4: Pemilihan matriks input dan teknik estimasi model. Matriks input dalam SEM dalam penelitian ini adalah matriks kovarians. 
Langkah 5: Estimasi model dengan program Analysis of Moment Structure (AMOS 22.0 Profesional). Estimasi identifikasi persamaan model dilakukan dengan menggunakan standard error yang besar untuk sebuah koefisien atau lebih, atau dengan kata lain, menggunakan korelasi yang tinggi $(\geq 0,90)$ di antara koefisien estimasi.

Langkah 6: Evaluasi model melalui ukuran goodness of fit, yaitu:

TABel 1. PEnguJian GOODNESS OF FIT

\begin{tabular}{lcc}
\hline \multicolumn{1}{c}{ Kriteria } & Nilai Cut-Off & Keterangan \\
\hline Chi Square & $\begin{array}{c}\text { Diharapkan kecil. } \\
\text { Prob. }>0,05\end{array}$ & Good Fit \\
Significance & $\geq 0,05$ & Good Fit \\
Probability & $\leq 0,08$ & Good Fit \\
RMSEA & $\geq 0,50$ & Good Fit \\
PGFI & $\geq 0,50$ & Good Fit \\
PNFI & $\leq 2$ atau 3 & Good Fit \\
CMIN/DF & $\geq 0,50$ & Good Fit \\
PCFI &
\end{tabular}

\section{HASIL DAN PEMBAHASAN}

\section{Uji Validitas}

Uji validitas konstruk dilakukan bertujuan untuk melihat indikator yang layak untuk mewakili konstruk pada penelitian ini. Pengujian dilakukan dengan menggunakan confirmatory factor analysis (CFA) pada masing-masing variabel laten dengan nilai loading factor $(\lambda) \geq 0.50$ dan memenuhi kriteria goodnessoffit.

\begin{tabular}{ccc} 
& TABeL 2.UjI VAliditaS & \\
\hline Indikator & Loading Factor & Validitas \\
\hline X1.1 & 0.877 & Valid \\
X1.2 & 0.758 & Valid \\
X1.3 & 0.759 & Valid \\
X2.1 & 0.744 & Valid \\
X2.2 & 0.894 & Valid \\
X2.3 & 0.723 & Valid \\
X3.1 & 0.710 & Valid \\
X3.2 & 0.758 & Valid \\
X3.3 & 0.896 & Valid \\
X4.1 & 0.851 & Valid \\
X4.2 & 0.947 & Valid \\
X4.3 & 0.880 & Valid \\
X4.4 & 0.882 & Valid \\
Z1 & 0.502 & Valid \\
Z2 & 0.913 & Valid \\
Z3 & 0.900 & Valid \\
Y1 & 0.951 & Valid \\
\hline
\end{tabular}

\begin{tabular}{rrr} 
Y2 & 0.899 & Valid \\
Y3 & 0.592 & Valid \\
\hline
\end{tabular}

Sumber: Data diolah 2017

\section{Uji Reliabilitas Konstruk}

Rumus uji reliabilitas konstruk:

$$
\mathrm{CR}=\frac{(\Sigma \lambda)^{2}}{(\Sigma \lambda)^{2}+\left(\Sigma\left(1-\lambda^{2}\right)\right)}
$$

Nilai reliabilitas masing-masing variabel $\oslash 0.70$ sehingga semua variabel reliable atau konsisten. Hubungan distributor dengan outlet 0.841, Kemampuan tenaga pemasaran 0.832, Citra Perusahaan 0.833, Strategi pelayanan outlet 0.930, Selling-In 0.829, dan Kinerja pemasaran 0.864.

\section{Uji Asumsi SEM}

Ukuran sampel, dalam penelitian ini sampel yang digunakan adalah 114 responden dan telah memenuhi syarat minimal uji asumsi SEM. Normalitas data, uji normalitas multivariat memberikan nilai CR sebesar 1.200 atau dibawah nilai standar 1.96, sehingga secara multivariat data berdistribusi normal.

Hasil uji outliers pada penelitian nampak pada Malahanobisdistance atau Mahalanobis $d$-squared sudah dihilangkan data yg ekstreem. Multikolinieritas, dari hasil analisis didapatkan hasil sampel kovarian matriks ,0000050679 maka tidak terdapat multikolinieritas data.

\section{Analisis $S E M$}

Hasil anlisis dan estimasi model dapat dijelaskan pada Gambar 2.berikut ini:

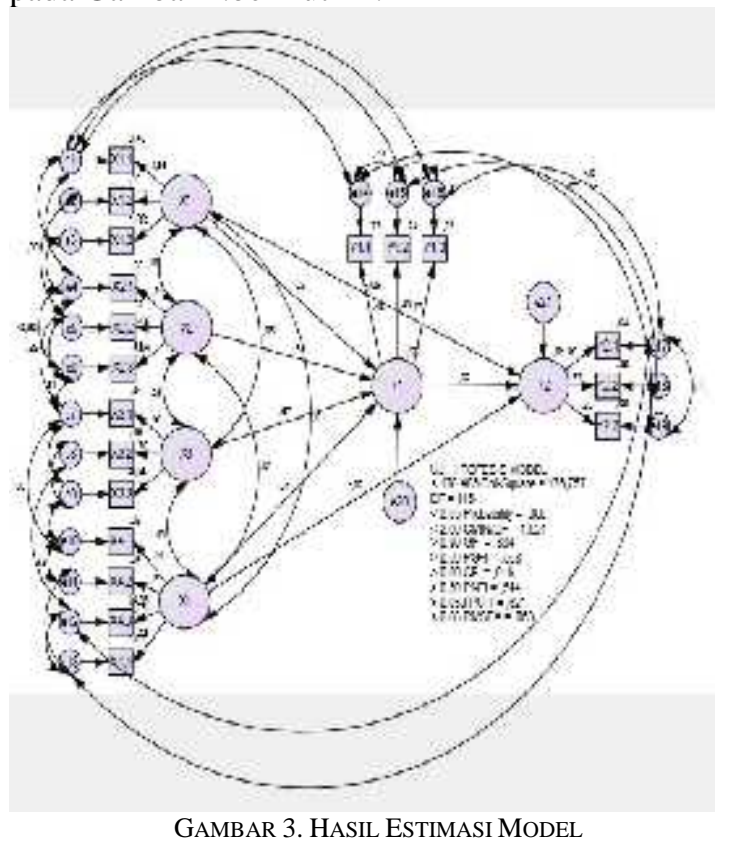

Uji Kesesuaian Model

Tabel 3.Hasil Pengujian Goodness of Fit

\begin{tabular}{cccc}
\hline Kriteria Nilai $C u t-$ & Hasil Ket. \\
\hline
\end{tabular}


Fredy Eka Ardhi Pratama, Hariadi Subagja, Ridwan Iskandar, Huda Ahmad Hudori, Paramita Andini. Pengaruh Kinerja Distribusi Selling-In Terhadap Kinerja Pemasaran PR. Gagak Hitam

\begin{tabular}{lccc}
\hline & Off & $\mathrm{Uji}$ & \\
\hline Chi & $\leq 178.485$ & 176.757 & Good Fit \\
Square & - & 149 & - \\
Df & $\geq 0.05$ & 0.000 & Marginal \\
Signifi- & & & \\
cance $P$. & & & \\
CMIN/DF & $\leq 2.00$ & 1.524 & Good Fit \\
GFI & $\geq 0,90$ & 0.864 & Marginal \\
PGFI & $\geq 0.50$ & 0.528 & Good Fit \\
CFI & $\geq 0,90$ & 0.916 & Good Fit \\
PNFI & $\geq 0,50$ & 0.544 & Good Fit \\
PCFI & $\geq 0,50$ & 0.621 & Good Fit \\
RMSEA & $\leq 0.08$ & 0.068 & Good Fit \\
\hline
\end{tabular}

Sumber: Data diolah 2017

Berdasarkan kriteria goodness of fit index pada

Tabel 3, nampak bahwa semua kriteria memiliki kecocokan (model baik) kecuali nilai significance probability dan nilai GFI yang masih dibawah nilai 0.90 namun dapat dikatakan memenuhi kriteria uji atau secara marjinal mendekati nilai kriteria dan nilai GFI tersebut menjelaskan bahwa $86.4 \%$ variabel bebas berkontribusi terhadap variabel terikat pada penelitian ini, dengan demikian hasil uji modifikasi model ini telah terpenuhi, maka model ini dapat diterima dan langkah selanjutnya menganalisis parameter estimate.

\section{Uji Kausalitas (Uji Hipotesis)}

TABEl 4. Hasil Uji KaUSALITAS

\begin{tabular}{|c|c|c|c|c|}
\hline \multicolumn{3}{|c|}{ Pengaruh Variabel } & \multirow{2}{*}{$\begin{array}{r}\text { C.R } \\
0.150\end{array}$} & \multirow{2}{*}{$\begin{array}{c}\mathrm{P} \\
0.881\end{array}$} \\
\hline $\begin{array}{l}\text { Hubugan } \\
\text { distributor }\end{array}$ & Thdp & $\begin{array}{l}\text { Selling- } \\
\text { In }\end{array}$ & & \\
\hline $\begin{array}{l}\text { Kemampuan } \\
\text { tenaga } \\
\text { pemasaran }\end{array}$ & Thdp & $\begin{array}{l}\text { Selling- } \\
\text { In }\end{array}$ & 2.767 & 0.006 \\
\hline $\begin{array}{l}\text { Citra } \\
\text { perusahaan }\end{array}$ & Thdp & $\begin{array}{l}\text { Selling- } \\
\text { In }\end{array}$ & 4.592 & $* * * *$ \\
\hline $\begin{array}{l}\text { Strategi } \\
\text { pelayanan } \\
\text { Outlet }\end{array}$ & Thdp & $\begin{array}{l}\text { Selling- } \\
\text { In }\end{array}$ & 1.464 & 0.143 \\
\hline Selling-In & Thdp & $\begin{array}{l}\text { Kinerja } \\
\text { Pemasaran }\end{array}$ & 0.196 & 0.844 \\
\hline $\begin{array}{l}\text { Hubugan } \\
\text { distributor }\end{array}$ & Thdp & $\begin{array}{l}\text { Kinerja } \\
\text { Pemasaran }\end{array}$ & -1.759 & 0.079 \\
\hline $\begin{array}{l}\text { Strategi } \\
\text { pelayanan } \\
\text { Outlet }\end{array}$ & Thdp & $\begin{array}{l}\text { Kinerja } \\
\text { Pemasaran }\end{array}$ & -0.830 & 0.407 \\
\hline
\end{tabular}

Sumber: Data diolah 2017

Berdasarkan Tabel 4, menunjukkan bahwa hubungan distributor dengan outlet $\left(\mathrm{X}_{1}\right)$ terhadap kinerja selling-in $(\mathrm{Z})$ tidak signifikan dengan $\mathrm{p}$ value sebesar 0,881 lebih besar dari 0.05 maka H0 diterima dan H1ditolak, selanjutnya kemampuan tenaga pemasaran $\left(\mathrm{X}_{2}\right)$ terhadap kinerja selling-in ( $\left.\mathrm{Z}\right)$ signifikan dengan $\mathrm{p}$ value sebesar 0,006 lebih kecil dari 0.05 maka H0 ditolak dan H1diterima. Citra perusahaan $\left(\mathrm{X}_{3}\right)$ terhadap kinerja selling-in $(\mathrm{Z})$ signifikan dengan $\mathrm{p}$ value sebesar 0,000 lebih kecil dari 0.05 maka H0 ditolak dan H1 diterima, sedangkan strategi pelayanan outlet $\left(\mathrm{X}_{4}\right)$ terhadap kinerja selling-in $(\mathrm{Z})$ tidak signifikan dengan $\mathrm{p}$ value sebesar 0,143 lebih besar dari 0.05 maka H0 diterima dan H1ditolak. Kinerja selling-in (Z) terhadap kinerja pemasaran ( $\mathrm{Y}$ ) tidak signifikan dengan $\mathrm{p}$ value sebesar 0,844 lebih besar dari 0.05 maka H0 diterima dan H1ditolak. Hubungan distributor dengan outlet $\left(\mathrm{X}_{1}\right)$ terhadap kinerja pemasaran tidak signifikan dengan $\mathrm{p}$ value sebesar 0,079 lebih besar dari 0.05 maka H0 diterima dan H1ditolak dan kemampuan tenaga pemasaran $\left(\mathrm{X}_{2}\right)$ terhadap kinerja pemasaran $\left(\mathrm{Y}_{2}\right)$ juga tidak signifikan dengan $\mathrm{p}$ value sebesar 0,407 lebih besar dari 0.05 H0 diterima dan H1ditolak.

\section{Pengaruh Antar Variabel \\ A. Pengaruh langsung}

Hasil pengujian pengaruh langsung antar variabel hubungan distributor dengan outlet, kemampuan tenaga pemasaran, citra perusahaan dan strategi pelayanan outlet terhadap kinerja selling-in serta kinerja selling-in, hubungan distributor dengan outlet dan strategi pelayanan outlet terhadap kinerja pemasaran. Variabel citra perusahaan menunjukkan pengaruh langsung yang paling dominan terhadap variabel kinerja selling-in yaitu nilai koefisien jalur pengaruh langsung sebesar 0.249 , sedangkan variabel hubungan distributor dengan outlet menunjukkan pengaruh langsung yang paling dominan terhadap variabel kinerja pemasaran yaitu nilai koefisien jalur pengaruh langsung sebesar -0.076 .

\section{B. Pengaruh tidak langsung}

Hasil pengujian pengaruh tidak langsung antar variabel hubungan distributor dengan outlet, kemampuan tenaga pemasaran, citra perusahaan dan strategi pelayanan outlet terhadap kinerja selling-in serta kinerja pemasaran. Variabel citra perusahaan menunjukkan pengaruh secara tidak langsung yang paling dominan terhadap terhadap variabel kinerja pemasaran yaitu nilai koefisien jalur pengaruh tidak langsung sebesar 0.009 , maka selain variabel hubungan distributor dengan outlet, kemampuan tenaga pemasaran, strategi pelayanan outlet dan kinerja selling-in secara tidak langsung variabel citra perusahaan yang menentukan kinerja pemasaran PR. Gagak Hitam.

\section{Pengaruh total}


Bahwa pengaruh total paling dominan dari variabel laten eksogen terhadap variabel laten endogen adalah pengaruh variabel citra perusahaan terhadap kinerja selling-in yaitu dengan koefisien jalur sebesar 0.249 yang menunjukkan bahwa citra perusahaan memiliki peranan yang sangat penting terhadap kinerja selling-in suatu perusahaan khususnya PR. Gagak Hitam selaku produsen dan distributor yang memasarkan produk melalui outlet rekanannya sedangkan pengaruh total terkecil adalah variabel kemampuan tenaga pemasaran terhadap kinerja pemasaran yaitu dengan nilai koefisien jalur sebesar 0.005 dimana PR. Gagak Hitam kurang memberikan tenaga lapang ahli atau salesforce yang berkualitas seperti kemampuan tenaga penjualan yang diukur keahlian, pengetahuan dan kemauan untuk dapat mengelola aktivitas kinerja selling-in melalui aktivitas presentasi penjualan, kemampuan mengelola informasi dan untuk pelanggan sehingga variabel yang memiliki peranan lebih terhadap kinerja pemasaran melalui kinerja selling-in yaitu citra perusahaan, hubungan distributor dengan outlet, dan strategi pelayanan outlet seperti yang disampaikan terhadap pengaruh langsung dan tidak langsung sebelumnya.

\section{KESIMPULAN DAN SARAN}

\section{A. Kesimpulan}

Berdasarkan hasil penelitian yang dilakukan, dapat disimpulkan bahwa :

1. Hubungan distributor dengan outlet berpengaruh langsung dan tidak signifikan terhadap kinerja selling-in PR. Gagak Hitam.

2. Kemampuan tenaga pemasaran berpengaruh langsung dan signifikan terhadap kinerja sellingin PR. Gagak Hitam.

3. Citra perusahaan berpengaruh langsung dan tidak signifikan terhadap kinerja selling-in PR. Gagak Hitam.

4. Strategi pelayanan outlet dengan outlet berpengaruh langsung dan tidak signifikan terhadap kinerja selling-in PR. Gagak Hitam.

5. Kinerja selling-in berpengaruh langsung dan signifikan terhadap kinerja pemasaran PR. Gagak Hitam.

6. Hubungan distributor dengan outlet berpengaruh langsung dan tidak signifikan terhadap kinerja pemasaran PR. Gagak Hitam.

7. Strategi pelayanan outlet berpengaruh langsung dan tidak signifikan terhadap kinerja pemasaran PR. Gagak.

\section{B. Saran}

Penelitian ke depan perlu menambah atau memasukkan konstruk variabel lain yang dapat berpengaruh terhadap kinerja selling-in sehingga nilai koefisien determinansinya dapat meningkat secara signifikan. Mengembangkan model diatas dengan menambahkan variabel kualitas produk sebagai variabel yang berdiri sendiri, menambahkan variabel baru yang belum diteliti pada model serta mengambil indikator pada model sebagai variabel baru.

\section{DAFTAR PUSTAKA}

[1] Kotler, Philip, (2007), "Marketing An Introduction Edisi Delapan”, Indeks, Jakarta.

[2] Sunaryo, Bambang B. (2002), "Dinamika Strategi Pelayanan Outlet dan Kinerja Pemasaran", Journal Sains Pemasaran Indonesia, Vol. 1, No. 1, Mei, p. 4156

[3] Arif, M Idris. (2004)," Analisis kinerja distribusi selling-in untuk meningkatkan kinerja pemasaran “Jurnal Sains Pemasaran Indonesia, Volume III, Nomor 1, p. 55-70

[4] Gamaliel, Fredrich, (2004), “ Analisis Faktor-faktor yang Mempengaruhi Keberhasilan Kinerja Selling-in terhadap Peningkatan Kinerja Pemasaran, Jurnal Sains Pemasaran Indonesia, Vol. III, Nomor 2, September 2004, p. 195-206.

[5] Ferdinand, Augusty T., 2004, " Strategic Selling-in Management", Research Paper Series 3, Program MM UNDIP, Semarang.

[6] Adikusumo, Susanti (2003) “ Analisis pengaruh kualitas hubungan bisnis antara tenaga penjualan dan retailer terhadap efektivitas penjualan “, Jurnal Sains Pemasaran Indonesia, Volume II, Nomor 3, p. 247264.

[7] Homburg, Christian Wayne D. Hoyer, \& Martin Fassnacht, (2002), " Service Orientation of a Retailer's Business Strategy : Dimensions, Antecedents, and Performance Outcomes ", Journal of Marketing. Vol. 66 (October),p. 86-101

[8] Gamaliel, Fredrich, (2004), “ Analisis Faktor-faktor yang Mempengaruhi Keberhasilan Kinerja Selling-in terhadap Peningkatan Kinerja Pemasaran, Jurnal Sains Pemasaran Indonesia, Vol. III, Nomor 2, September 2004, p. 195-206.

[9] Ghozali, I. 2005. Aplikasi Analisis Multivariat dengan Program SPSS. Semarang: Badan Penerbit Universitas Diponegoro. 